\title{
Analyzing the Influence of Computer Capabilities and Knowledge Sharing in the fulfillment of Information System
}

\author{
Hosein Rezaie Dolatabadi (Ph.D) \\ Faculty member of Department of Management, University of Isfahan, Iran
}

\begin{abstract}
Ali Hoseini
M.A. Student a Department of Management, University of Isfahan, Iran

Hoseini.ali65@yahoo.com

Hamed Derakhshide

M.A Student of Business Management at University of Isfahan, Iran hamedderakhshide@gmail.com
\end{abstract}

Accepted: May 28, 2012 Published: July 25, 2012

Doi:10.5296/ijld.v2i4.2143 URL: http://dx.doi.org/10.5296/ijld.v2i4.2143

\begin{abstract}
Purpose-the Purpose of this research is to empirically validate a conceptual model to understand the effect Computer Self-Efficacy (CSE) on collegial knowledge sharing (CKS), Technical knowledge sharing (TKS), and use of information system (UIS) in the workplace.

Design/methodology/approach- Based on a survey of 102 employees from 138 organizations in the Fourth International Exhibition of Building Materials and Technology and elevators, lifts, industrial equipment. This International Exhibition was held in Isfahan (Iran), October 2011.

Findings -CSE has effective on CKS, TKS and UIS; TKS has effective on UIS and CKS has not effective in UIS in the Workplace.

Practical implications-The results point to the importance of the roles of CSE and Knowledge sharing as factors of effective in use of IS.
\end{abstract}


Originality/value: four phases of management information system (MIS) are studied; CSE, CKS, TKS, and UIS in IT-related SMEs and this study demonstrate how these processes are relevant.

Keywords - Computer Self-Efficacy (CSE), collegial knowledge sharing (CKS), Technical knowledge sharing (TKS) and, Use of information technology (UIS).

\section{Introduction}

Information systems (IS) usage has increased dramatically in business operations over the past two decades, creating interest in users' limited acceptance of IS. Given that organizations have made considerable IS investments, users' limited acceptance of IS prevents these organizations from reaching full potential of their investments (Saeed \& Abdinnour-Helm, 2008).During the past two decades, there has been a growing body of research that seeks to determine the constructs that lead to the acceptance of IS and ultimately its use (Compeau \& Higgins, 1995; Gefen, Karahanna, \& Straub, 2003; Lai \& Li, 2005; Legris et al., 2003; Venkatesh, Morris, Davis, \& Davis, 2003).

Among the various user-acceptance models, a common premise of user acceptance of IS is explaining the behavioral intention to use the system (Agarwal \& Karahanna, 2000). Subsequently, IS acceptance theories and models have generally focused upon predictors or determinants of acceptance such as ease of use, usefulness, physical system attributes, and individual characteristics such as computer anxiety and self-efficacy (Agarwal \& Prasad, 1999, Venkatesh, 2000).

Thus, this research was designed to empirically validate the effects of computer self-efficacy (CSE) in predicting knowledge sharing and use of IS in the workplace. In addition, this study addressed a gap in the CSE literature linking knowledge sharing and to individual's use of IS. The main research question is in this research: What role do users' CSE play in influencing collegial and technical knowledge sharing and their use of IS in the workplace? This study examined the usage of IS in a business environment setting within the Fourth International Exhibition of Building Materials and Technology (Lightweight construction - Retrofitting) and elevators, lifts, industrial equipment. This International Exhibition was held in Isfahan (Iran). With these objectives in mind, Section 2 proposes a model of CSE, CKS, TKS and UIS, and the authors present a number of testable hypotheses. Section 3, outlines the research methodology, including a description of the data collection and statistical procedures; the authors use a structural equation modeling to empirically assess a sample of SMEs that compete in IS-related activities. In Section 4, the authors discuss study findings, and finally, Section 5 summarizes the main conclusions.

\section{Conceptual model and hypotheses}

The proposed conceptual model assumes that Computer Self-Efficacy (CSE) affection on collegial knowledge sharing (CKS), Technical knowledge sharing (TKS) and the use of IS in the organization. Following each of these concepts described briefly.

\subsection{Self-Efficacy and Computer Self-Efficacy (CSE)}

Bandura (1986) defined self-efficacy as "people's judgments of their capabilities to organize and execute courses of action required to attain designated type of performance". This 
definition highlights a key aspect of the self-efficacy construct. Specifically, it indicates the importance of not just component skills but the ability to organize and execute a course of action.

The concept of computer self-efficacy (CSE) emerged from the self-efficacy literature (Compeau \& Higgins, 1995). Compeau and Higgins (1995) defined CSE as "a judgment of one's capability to use a computer" (p. 192). Research has also suggested that those individuals who have high CSE beliefs are more likely to report higher perceptions of usefulness and perceptions of ease of use (Marakas et al., 1998). In addition, Marakas et al (1998) found that CSE positively influences beliefs about use of IS. Likewise, Hsu and Chiu (2004) found that CSE had positive effects on IS usage. In the IS literature, a significant body of research has focused on studying CSE as a determinant of IS acceptance and use (Legris et al., 2003; Money \& Turner, 2005; Venkatesh et al., 2003)

\subsection{Collegial Knowledge Sharing (CKS)}

At first concept of sharing knowledge examined. Ipe (2003) defined knowledge sharing as a process that transforms knowledge held by an individual and converts it into a format that can be understood, absorbed, and used by other individuals. Ipe (2003) also identified factors that influence knowledge sharing, such as motivation to share, perceived power attached to the knowledge, reciprocity, and relationship with the recipient involving matters such as trust and rewards.

First dimension of sharing knowledge is Collegial Knowledge Sharing or In other words is concerned to person's collegial skill in the use of computers and information systems. Collegial support is defined as the extent to which the user can rely on the expertise of colleagues who have used the computer for similar tasks (Deng et al., 2004). Locke, Frederick, Lee, \& Bobko (1984) suggested that individuals could improve their computer self-efficacy by learning computer skills from other colleagues.

Nonaka and Konno (1998) suggested that organizational members can absorb new knowledge from their colleagues to be leveraged by organizations. Other IS literature suggested that the individual's reference groups within an organization result in knowledge sharing which may keep knowledge and information obtained from various sources current in order to serve as a guide for future action (Lukas, Hult, \& Ferrell, 1996). Sheng et al. (2003) suggested that individual reference groups encourage cooperation and coordination. According to Sheng et al. (2003), individuals within a supportive group environment are willing to help each other with performing tasks on computers.

\subsection{Technical Knowledge-Sharing (TKS)}

Another way to facilitate knowledge is through the organization's technical support. This external construct has a positive influence on attitude, usage, and behavioral expectation (Compeau, Higgins, \& Huff, 1999). In order to improve self-efficacy, technical support facilitates IS use. Technical support refers to availability of specialized personnel (e.g., help desk, information center) to answer questions regarding IS use and provides hands-on support to users before and during usage of IS (Bhattacherjee \& Hikmet, 2008). Indeed, most of the research found a positive link between the human-assisted dimension of CSE and one's ability 
to use IS with support from other individuals (Lee \& Kim, 2009; Thatcher et al., 2008). According to Lee and Kim (2009), technical support extends human-assisted support and helps build self-efficacy.

\subsection{Use of Information Systems (UIS) Measure}

The role of information systems is integration and coordination between organization different parts and these systems have a direct impact on user's performance and efficiency. According to Westland and Clark (2000), in the 1980 decade approximately 50\% of investment companies have paid for the deployment of information systems. In this research from Participants were asked to rate the amount of time spent using IS in their workplace, and how often usage occurred. Table I shows a list that includes each construct together with its related items and the studies from which the constructs were derived.( Table I)

Table I: Constructs and items

\begin{tabular}{|c|c|c|c|}
\hline Dimension & Study & $\begin{array}{l}\text { Instrument } \\
\text { /Constructs }\end{array}$ & Main Findings or Contribution \\
\hline $\begin{array}{l}\text { Knowledge } \\
\text { Sharing }\end{array}$ & $\begin{array}{l}\text { Marouf,2007 } \\
\text { Bhattacherjee, } \\
\text { Hikmet, } 2008\end{array}$ & $\begin{array}{l}\text { Knowledge } \\
\text { sharing } \\
\text { Two } \\
\text { organizational } \\
\text { support factors: } \\
\text { infrastructure } \\
\text { support and } \\
\text { technical support }\end{array}$ & $\begin{array}{l}\text { Study found that business relationship } \\
\text { had more dominance on knowledge } \\
\text { sharing than social relationships. } \\
\text { Study confirmed that organizational } \\
\text { support plays a critical role in } \\
\text { influencing user perceptions toward } \\
\text { IT and users' subsequent IT usage. }\end{array}$ \\
\hline $\begin{array}{l}\text { Computer } \\
\text { Self-Efficac } \\
\mathbf{y}\end{array}$ & $\begin{array}{l}\text { Ndubisi , Jantan, } \\
2003 \\
\text { Levy \& Green, } \\
2009\end{array}$ & $\begin{array}{l}\text { Computing skills, } \\
\text { technical backing, } \\
\text { perceived } \\
\text { usefulness, } \\
\text { perceived } \\
\text { ease-of-use, } \\
\text { information } \\
\text { system usage } \\
\text { behavior } \\
\text { Computer } \\
\text { self-efficacy, }\end{array}$ & $\begin{array}{l}\text { Study found that computing skill and } \\
\text { technical support positively impact } \\
\text { user's perception of the usefulness } \\
\text { and ease of use of information } \\
\text { systems. } \\
\text { Study found that computer } \\
\text { self-efficacy significantly influences } \\
\text { sailors perception of system } \\
\text { usefulness and ease of use. }\end{array}$ \\
\hline
\end{tabular}




\begin{tabular}{|c|c|c|c|}
\hline & & $\begin{array}{l}\text { perceived } \\
\text { usefulness, } \\
\text { perceived } \\
\text { ease-of-use, } \\
\text { attitude, } \\
\text { behavioral } \\
\text { intention }\end{array}$ & \\
\hline $\begin{array}{l}\text { use of } \\
\text { information } \\
\text { system }\end{array}$ & $\begin{array}{l}\text { Maguire, } \quad \& \\
\text { Redman, (2007) }\end{array}$ & $\begin{array}{l}\text { Information } \\
\text { systems, Human } \\
\text { resource } \\
\text { management, } \\
\text { Integration, } \\
\text { Change management } \\
\text { Paper type } \\
\text { Research paper }\end{array}$ & $\begin{array}{l}\text { The research finds that IS failure is } \\
\text { often associated with a lack of } \\
\text { attention to "softer" } \\
\text { management practices such as culture } \\
\text { change, organization development } \\
\text { and user involvement. The } \\
\text { findings of the case study research } \\
\text { suggest that HR has a key but } \\
\text { neglected potential role to play in } \\
\text { successful IS implementation. }\end{array}$ \\
\hline
\end{tabular}

So According to the above description was developed following hypothesis for this research.

H1: users' CSE will exert a positive influence on CKS.

H2: users' CSE will exert a positive influence on TKS.

H3: users' CSE will exert a positive influence on UIS in the workplace.

H4: CKS will exert a positive influence on UIS.

H5: TKS will exert a positive influence on UIS in the workplace.

The hypotheses established above are shown in the conceptual model of Computer Self-Efficacy, Collegial knowledge sharing, Technical knowledge sharing and uses of IS in the workplace as illustrated in Figure This model comprises five, interrelated dimensions:

1. Computer Self-Efficacy (CSE)

2. Collegial knowledge sharing (CKS)

3. Technical knowledge sharing (TKS)

4. Uses of IS in the workplace (UIS). (Figure 1) 


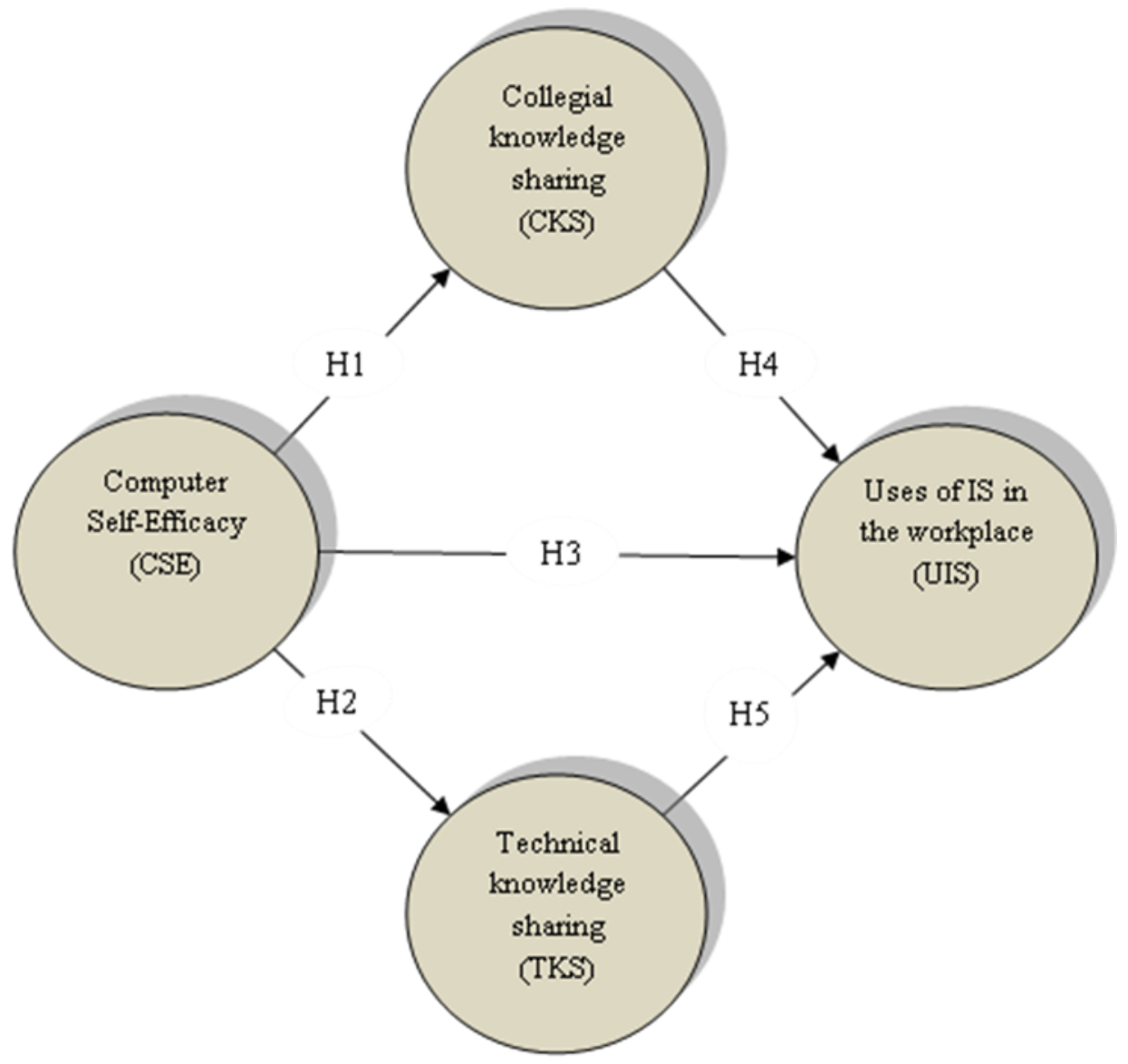

Figure 1: SEM, CKS, TKS, EBO, UIS conceptual model

\section{Method}

\subsection{Sample profile and data collection}

Statistical population of the research is the Fourth International Exhibition of Building Materials and Technology (Lightweight construction - Retrofitting) and elevators, lifts, industrial equipment. This International Exhibition was held in Isfahan (Iran), October 2011. 28 elevator companies And 110 the building materials and technology companies attended in this the International Exhibition. All 138 inquired firms agreed to participate in this study. The sample population for this study was 190 participants within these companies. The final sample includes 102 (53\%) employees, implying between one and tow questionnaires per firm, with a sampling error of 9.62 percent at a 95 percent confidence level $(\mathrm{z}=1.96, \mathrm{p}=\mathrm{q}=50$ percent). According to Leedy and Ormrod (2005), a sample of $25 \%$ to $30 \%$ of the population is adequate for survey-based research.

For this study, a specific questionnaire was designed making use of constructs identified impervious studies related with Computer Self-Efficacy, knowledge sharing, and use of IS in the workplace. The questionnaire was adapted from research questionnaire of Lychvar and 


\section{Macrothink $\Delta$ Institute ${ }^{\text {th }}$}

Bernard (2011). The constructs were operational with items adapted from those studies and modified for use knowledge sharing, Computer Self-Efficacy and use of IS in the workplace.

This study used a five-part questioner instrument that the questionnaire had 15 questions. All items were measured using multiple items and a five-point, Likert-type scale (ranging from strongly disagree (1) to strongly agree (5)). The instrument addressed participant's collegial knowledge-sharing (CKS) and participant's technical knowledge-sharing (TKS) behavior, computer self-efficacy CSE and use of information systems (UIS), and demographic information. The first section consisted of three items (Q1, Q2, Q3) to measure (CKS), and the second section consisted of four items (Q4, Q5, Q6, Q7) to measure technical knowledge sharing (TKS). And the third section contained three items (Q8, Q9, Q10) to measure CSE. Section fourth consisted of five items (Q11, Q12, Q13, Q14, Q15) to measure the use of information systems (UIS). The last section gathered general information regarding participant's gender, age, educational degree, organization, and number of years of employment with the company. Table II provides the descriptive statistics and demographics of the data collected.

Table II: Descriptive Statistics and Demographics $(\mathrm{N}=102)$

\begin{tabular}{|c|c|c|c|}
\hline & Item & Frequency & Percentage (\%) \\
\hline \multirow[t]{2}{*}{ Gender } & Male & 76 & 74 \\
\hline & Female & 26 & 26 \\
\hline \multirow[t]{5}{*}{ Age } & $19-26$ & 35 & 34 \\
\hline & $27-34$ & 59 & 57 \\
\hline & $42-35$ & 6 & 6 \\
\hline & $43-56$ & 1 & 1 \\
\hline & 67 or Older & 1 & 1 \\
\hline \multirow[t]{5}{*}{ Education } & High School Diploma & 8 & 8 \\
\hline & Associate Degree & 10 & 10 \\
\hline & Bachelor Degree & 71 & 70 \\
\hline & Master Degree & 13 & 12 \\
\hline & $\begin{array}{l}\text { Doctorate Degree (Ph.D or } \\
\text { Ed.D) }\end{array}$ & 0 & 0 \\
\hline \multirow[t]{6}{*}{ Years of Service } & 1 year or less & 28 & 27 \\
\hline & $1-5$ & 48 & 47 \\
\hline & $6-9$ & 20 & 20 \\
\hline & $10-13$ & 4 & 4 \\
\hline & $14-20$ & 1 & 1 \\
\hline & 21 years or longer & 1 & 1 \\
\hline \multirow[t]{3}{*}{ Organization } & Education & 1 & 1 \\
\hline & Government & 4 & 4 \\
\hline & Services & 22 & 21 \\
\hline
\end{tabular}




\begin{tabular}{|l|l|l|l|}
\hline \hline \multirow{2}{*}{} & Manufacturing & 48 & 47 \\
\cline { 2 - 4 } & Real Estate & 10 & 10 \\
\cline { 2 - 4 } & Information Technology & 7 & 7 \\
\cline { 2 - 4 } & Others & 10 & 10 \\
\hline
\end{tabular}

\section{Data analysis and results}

Measurement model .In this first step, each construct was evaluated by measuring its unitdimensionality, reliability and validity.

This study used a panel of experts to determine the concept validity of the modified items in the survey instrument and participants from a local university to participate in a pretest of the survey instrument and The Cronbach Alpha reliability test was conducted on CKS, TKS, CSE and UIS constructs to determine the internal consistency across each measure item. According to Vitari et al. (2007), a Cronbach Alpha score over .70 represents a reliable factor. To determine reliability, 30 questionnaires were distributed and compiled in a statistical population. The reliability results of this research produced five factors with Cronbach Alpha of .743, .726,.705 and .70 corresponding with CKS, TKS, CSE, UIS and respectively, indicating reliable factors.

The measurement model was assessed using a confirmatory factor analysis (CFA). Table III shows the results of this test. All questions except Q7, loadings exceed 0.5. This factor were excluded from analysis Because of factor loading less than 0.5. In terms of the average variance extracted, all constructs exceed the suggested value of 0.5 (Bagozzi and Yi, 1988), indicating the measure has adequately convergent validity (see Table III). 


\section{N Macrothink $\Lambda$ Institutem}

Table III: scale for variables

\begin{tabular}{|l|l|l|}
\hline Construct & $\begin{array}{l}\text { Indicators/ } \\
\text { items }\end{array}$ & $\begin{array}{l}\text { Factor } \\
\text { loading }\end{array}$ \\
\hline \multirow{4}{*}{ CKS } & Q1 & .75 \\
& Q2 & .73 \\
& Q3 & .63 \\
\hline \multirow{5}{*}{ TKS } & Q4 & .65 \\
& Q5 & .65 \\
& Q6 & .78 \\
\hline \multirow{5}{*}{ CSE } & Q8 & .57 \\
& Q9 & .62 \\
& Q10 & .84 \\
\hline \multirow{5}{*}{ UIS } & Q11 & .60 \\
& Q12 & .52 \\
& Q13 & .54 \\
& Q14 & .57 \\
& Q15 & .56 \\
\hline
\end{tabular}

After this initial analysis had been conducted, the data was loaded into the SPSS $®$ Analysis of Moment Structures (AMOS18) statistical package for further evaluation using the a structural equation modeling (SEM) as a means to test possible cause-and-effect relationships of the conceptual model.

The SEM shows the interaction between the theory and the empirical data. In addition, it allows us to test the causal relationships between constructs that feature multiple measurement items (Joresko"g and Sorbom, 1996). The authors built two-stage model to apply SEM. First the measurement model to perform instrument validation was examined. Then the structural model was used to test the hypotheses (Laura Zapata Cantu', Josep Rialp Criado and Alex Rialp Criado, 2009).

Structural model: According to Simon and Paper (2007), literature suggested that SEM is an appropriate technique for a model-fit examination, superior to multiple regression analysis. In fact, literature suggested there are seven common measures of model-fit analysis (Levy \& Green, 2009). These measures include chi-square/degrees-of-freedom (Chi-square/df); goodness-of-fit index (GFI), adjusted goodness-of-fit-index (AGFI), normed fit index (NFI), information fit index (IFI), comparative fit index (CFI), and root mean squared error of approximation (RMSEA).The results of the analysis are illustrated in table IV. 
Table IV: Summary of the Conceptual Model Tests $(\mathrm{N}=102)$

$\begin{array}{lllllll}\mathbf{X}^{2} / \mathbf{D F} & (\mathbf{I F I}) & (\mathbf{G F I}) & (\mathbf{A G F I}) & (\mathbf{N F I}) & (\mathbf{C F I}) & \text { (RMSEA) } \\ 1.46 & .93 & .87 & .81 & .831 & .94 & .07\end{array}$

Structural model .The first step was to obtain the goodness-of-fit of the model hypothesized in Figure 2. $\mathrm{X}^{2} / \mathrm{DF}$ (1.46 Less than five) corresponds to a satisfactory adjustment. The other adjusted indices $(\mathrm{CFI}=.94, \mathrm{IFI}=.93, \mathrm{GFI}=.87, \mathrm{NFI}=.83, \mathrm{AGFI}=.81)$ and the root mean of the index's squared residual (RMSR $=.07)$ are within acceptable ranges. This implies a substantial amount of variance in the model (Bagozzi and Yi, 1988) and fit to the model. The results of the analysis are illustrated in Figure 2.

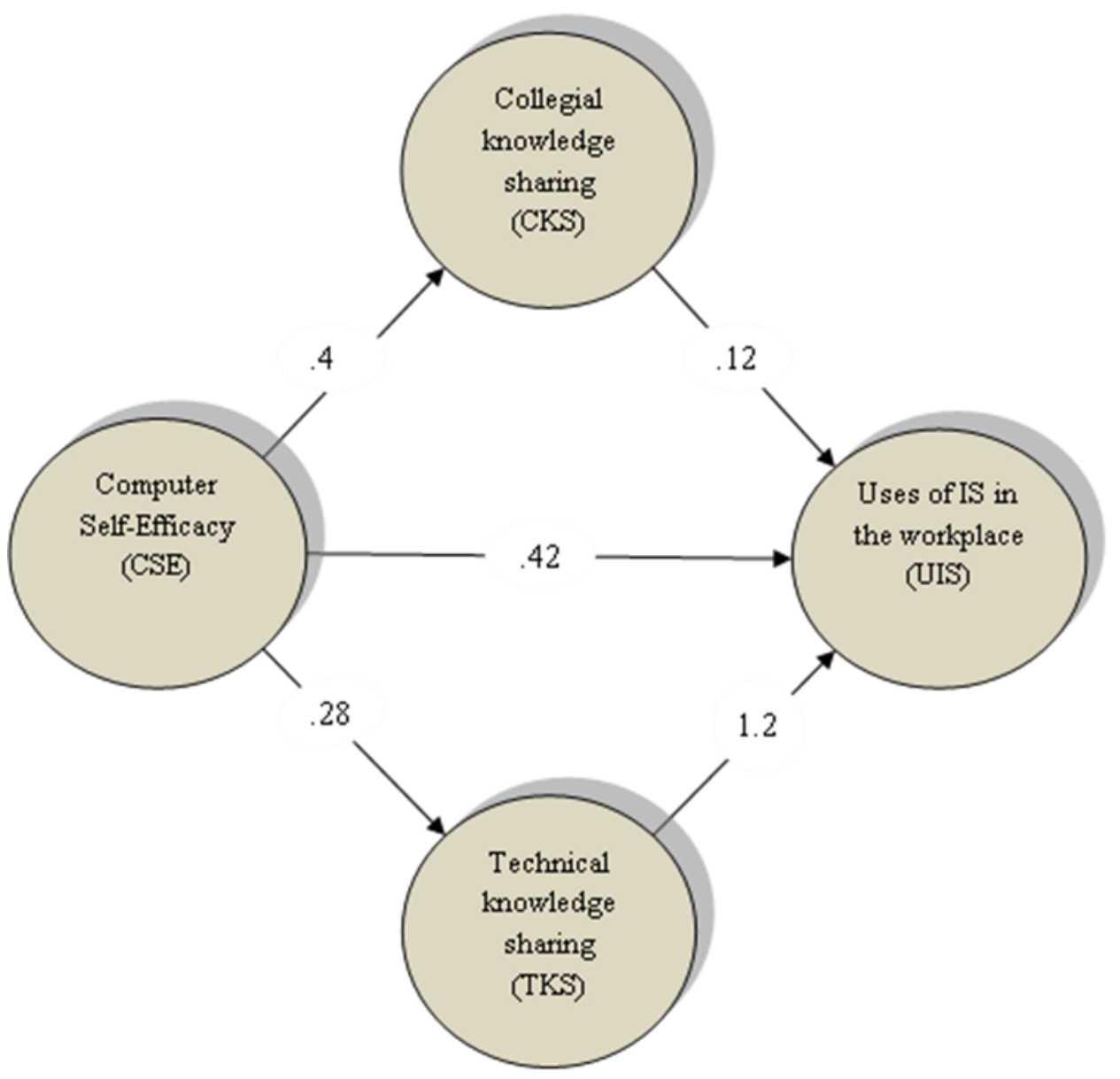

Figure 2 : structural model of the causal relationship between SEM, CKS, TKS, and UIS

Path analysis was used to empirically test the conceptual model and provided quantitative estimates of relationships between variables. The findings in Table V indicate Maximum Likelihood Estimates for hypothesized paths. 
Table V: Maximum Likelihood Estimates for Hypothesized Paths

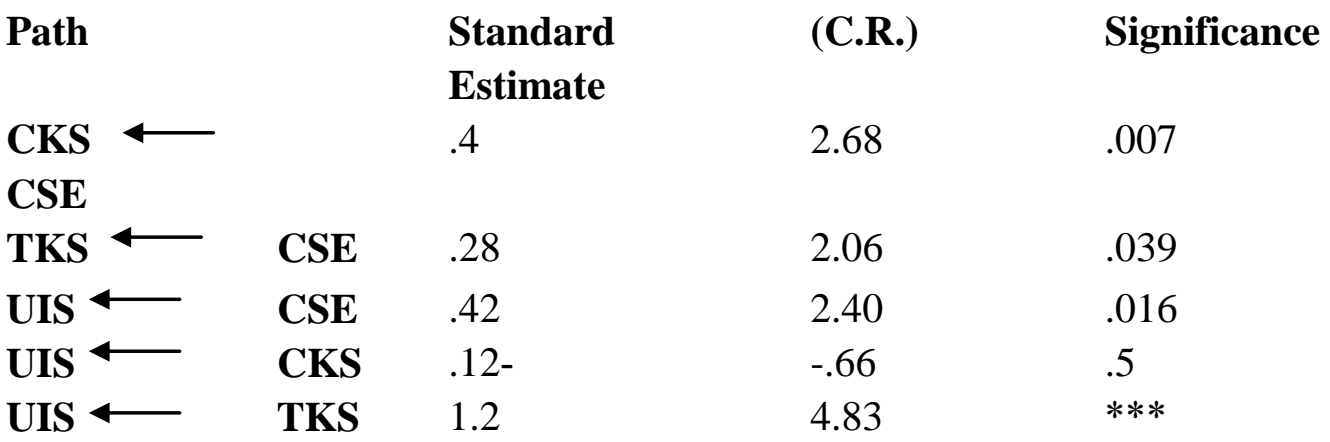

Finally Table VI summarizes the results of the tests of the hypotheses. CSE had significant relationship with CKS, i.e., H1 was supported. CSE had a significant relationship with TKS, i.e., H2 was supported. CSE had a significant relationship with UIS, i.e., H3 was supported. CKS had no a significant influence on UIS, i.e., H4 was not supported. TKS had a significant influence on Use of Information Technology (UIS), i.e., H5 was supported.

Table VI: Summary of Hypotheses Results

\begin{tabular}{|l|l|}
\hline Hypotheses & Results \\
\hline H1: users' CSE will exert a positive influence on CKS. & Supported \\
\hline H2: users' CSE will exert a positive influence on TKS & Supported \\
\hline H3: users' CSE will exert a positive influence on UIS & Supported \\
\hline H4: CKS will exert a positive influence on UIS. & Not Supported \\
\hline H5: TKS will exert a positive influence on UIS. & Supported \\
\hline
\end{tabular}

\section{Conclusions, limitations and future research implications}

This study examined the ability of Computer Self-Efficacy and knowledge sharing to predict sharing knowledge and use of IS in the workplace. The main research question addressed in this research was: What role does users' Computer Self-Efficacy play in influencing on use of IS in the workplace? This study addressed five specific hypotheses that the hypotheses 1, 2, 3 and 5 were supported. So According to the results of this paper is essential that the people have computer skills facilitate the process of sharing knowledge in dimensions the technical and academic in organizations until share knowledge become a common fair organization in the field of computer technology and information systems, In this case, the IT department Make familiar employees in the organization that how they use of computer technology and 


\section{Al Macrothink}

International Journal of Learning \& Development

ISSN 2164-4063

2012, Vol. 2, No. 4

information systems because of The Department of IT setup Sharing knowledge in dimension of the technical.

Although this study provided some insight on the impact of CSE on knowledge sharing and encouragement by others and the use of IS in the workplace, more research is undoubtedly needed to provide further understanding of these variables in work environments. First, the non-significant effect of collegial knowledge sharing on UIS warrants additional investigation. Given that perceptions of data gathered on collegial knowledge sharing and UIS, a negative path coefficient would be a promising area for future research. Another interesting research area would be the mediating role of CSE between knowledge sharing and use of IS in the workplace that was supported in this model. Ultimately, future research could examine the elimination of knowledge sharing and encourage by others within this study model to determine the influence of and CSE on these IS in the workplace. 


\section{References}

1. Agarwal, R. \& Karahanna, E (2000). Time flies when you're having fun: Cognitive absorption and beliefs about information technology usage. MIS Quarterly, 24(4), 665-694.

2. Agarwal, R. \& Prasad, J (1999)"Are individual differences germane to the acceptance of new information technologies", Decision Sciences, 30(2), 361-391.

3. Bhattacherjee, A., \& Hikmet, N. (2008). Reconceptualizing organizational support and its effect on information technology usage: Evidence from the health care sector .Computer Information Systems, 48(4), 69.

4. Bock, G., Zmud, R.W., Kim, Y. \& Lee, J. (2005). Behavioral intention formation in knowledge sharing: Examining the roles of extrinsic motivators, social-psychological forces, and organizational climate. MIS Quarterly, 29(1), 87-111.

5. Bryant, S. E. (2005). The impact of peer mentoring on organizational knowledge creation and sharing: An empirical study in a software firm. Group and Organization Management, 30(3), 319-338.

6. Compeau, D. \& Higgins, C (1995).Computer self-efficacy: Development of a measure and initial test. MIS Quarterly, 19(2), 189-211.

Compeau, D., Higgins, C., \& Huff, S. (1999). Social cognitive theory and individual reaction to computing technology: A longitudinal study. MIS Quarterly, 23(2), 145-163.

7. Compeau, D., Higgins, C., \& Huff, S. (1999). Social cognitive theory and individual reaction to computing technology: A longitudinal study. MIS Quarterly, 23(2), 145-163.

8. Compeau, D., Higgins, C., \& Huff, S. (1999). Social cognitive theory and individual reaction to computing technology: A longitudinal study. MIS Quarterly, 23(2), 145-163.

9. Das, A. (2003). Knowledge and productivity in technical support work. Management Science, 49(4), 416-431.

10. Davenport,T. H., \& Prusak, L. (2000). Working knowledge: How organizations manage what they know. Boston, Mass: Harvard Business School Press.

11. Deng, X., Doll, W. \& Truong, D (2004)"Computer self-efficacy in an ongoing use context", Behavior and Information Technology, 23(6), 395-412.

12. Gefen, D., Karahanna, E ., \& Straub, W. (2003). Trust and TAM in online shopping: An integrated model. MIS Quarterly, 27(1), 51-90.

13. Haas, M. R. \& Hansen, M. T. (2005). When using knowledge can hurt performance: The value of organizational capabilities in a management consulting company. Strategic Management Journal, 26(1), 1-24.

14. Hildreth, P., Kimble, C. \& Wright, P. (2000)" Communities of practice in the distributed international environment", Journal of Knowledge Management,4(1), 27.

15. Hsu, M. H., \& Chiu, C. M. (2004)"Internet self- efficacy and electronic service acceptance", Decision Support Systems, 38(3), 369-381.

16. Hsu, M.H., Ju, T., Yen, C.-H. ,\& Chang, C.-M. (2007). Knowledge sharing behavior in virtual communities: The relationship between trust, self-efficacy, and outcome expectations. International Journal Human-Computer, 65, 153-169.

17. Ipe, M. (2003).Knowledge sharing in organizations: A conceptual framework. Human Resource Development Review, 2(4), 337-359. 
18. Lai, S., \& Li, H. (2005)" Technology acceptance model for internet banking: An invariance analysis", Information \& Management, 42(1), 373-386.

Lee, S. \& Kim, B. G. (2009)" Factors affecting the usage of intranet: A confirmatory study", Computers in Human Behavior, 25(1), 191-201.

19. Legris, P., Ingham, J. \& Collerette, P (2003)"Why do people use information technology? A critical review of the technology acceptance model ",Information \& Management, 40, 191-204.

20. Lu, H.P. \& Hsiao, K. L (2007)"Understanding intention to continuously share information on weblogs " , Internet Research, 17(4), 345-361.Management Journal, Vol. 20, pp. 595-623.

21. Maguire, S. \& Redman, T. (2007).The role of human resource management in information systems development, Management Decision, Vol. 45 No. 2, pp. 252-264.

22. Marakas, G. M., Yi, M. Y., \& Johnson, R. D (1998)" The multi-level and multi-faceted character of computer self-efficacy: Toward clarification of the construct and an integrative framework for research", Information systems research, 9, 126-163.

23. Money, \& Turner, A. (2005).Assessing knowledge management system user acceptance with the technology acceptance model .International Journal of Knowledge Management, 1(1), $8-26$.

24. Nonaka, I., \& Konno, N. (1998). The concept of "ba": Building a foundation for knowledge creation. California Management Review, 40(3), 40-54.

25. Saeed, K. A., \&Abdinnour-Helm, S. (2008).Examining the effects of information system characteristics and perceived usefulness on post adoption usage of information systems. Information \& Management, 45, 376-386.

26. Sheng ,Y., Pearson, M., \& Crosby, L. (2003).Organizational culture and employees' computer self- efficacy: An empirical study. Information Resources Management, 16(3), $42-58$.

27. Simon, S. J., \&Paper, D.(2007). User acceptance of voice recognition technology: An empirical extension of the technology acceptance model. Journal of Organizational and End User Computing, 19(1), 24-50.

28. Thatcher, J. B., Zimmer, C., Gundlach, J., \& McKnight, D. H. (2008) .Internal and external dimensions of computer self-efficacy: An empirical examination. IEEE Transactions on Engineering Management, 55(4), 628-644.

29. Thompson, R., Compeau, D., \& Higgins, C. (2006). Intentions to use information technologies: An integrative model. Journal of Organizational and End User Computing, $18(3), 25-37$.

30. Venkatesh ,V. ,Morris, M. G., Davis, G. B., \& Davis, F. D. (2003). User acceptance of information technology: Toward a unified view. MIS Quarterly, 27(3), 425-478.

31. Venkatesh, V (2000)" Determinants of perceived ease of use: Integrating control, intrinsic motivation, and emotion into the technology acceptance model ", Information Systems Research, 11(4), 342-365.

32. Venkatesh, V. \& Davis, D (2000)" A theoretical extension of the technology acceptance model: Four longitudinal field studies", Management Science, 46(2), 186-204. 


\section{Macrothink

33. Vitari, C., Moro, J . Ravarini, A., \& Bourdon, I. (2007). Improving KMS acceptance: The role of organizational and individuals' influence. International Journal of Knowledge Management, 3(3), 68-90.

34. Westland, J. C. and Clark, T. H. (2000)" Global electronic commerce: Theory and case studies", Cambridge, MA: MIT Press. 